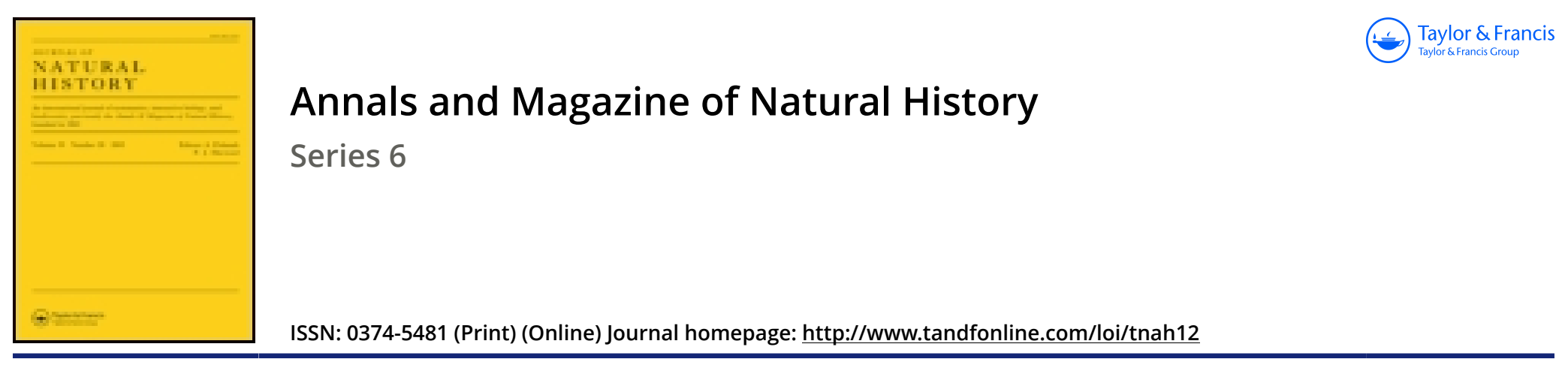

\title{
LIII.-Descriptions of two new reptiles obtained by Mr. A. S. Meek in the Trobriand Islands, British New Guinea
}

\section{G.A. Boulenger F.R.S.}

To cite this article: G.A. Boulenger F.R.S. (1895) LIII.-Descriptions of two new reptiles obtained by Mr. A. S. Meek in the Trobriand Islands, British New Guinea, Annals and Magazine of Natural History, 16:95, 408-409, DOI: 10.1080/00222939508680292

To link to this article: http://dx.doi.org/10.1080/00222939508680292

曲 Published online: 06 Oct 2009.

Submit your article to this journal $\pi$

Џll Article views: 4

Q View related articles $\sqsubset$ 
that it is $a$ species of Taphes; but the specimen being unique and fragile, has not been thoroughly examined.

\section{Tenebrionidæ.}

Pedinus (Blindus) japonicus, Seidlitz in litt.

In the Ins. Deutschland, v. p. 876 (1893), Dr. Georg Seidlitz notices? in the middle of a long paper on European Coleoptera (a mode of publication certainly open to censure), a Japanese species of Pedimus. He says perhaps it is a variety of $P$. strigosus, a well-known and very common Jrpanese insect, but his descriptive lines are not sufficient to entitle his name to more than a manuscript value. All he says is "prothorace basi parum emarginato, punctis vix elongatis, haud confluentibus obsito, femoribus posticis maris paullo curvatis, subtus basi tenuiter pubescentibus." L. 8-9 mill. Dr. Seidlitz's specimens came from Hildendorf, whose collections, some years prior to 1893 , were examined and written about by Harold, and it seems probable Harold saw the specimens to which Seidlitz refers.

LIII.-Descriptions of Two new Reptiles obtained by Mr. A. S. Meek in the Trobriand Islands, British New Guinea. By G. A. Boulenger, F.R.S.

\section{Lygosoma longiceps.}

Section Liolepisma. Habit lacertiform; the distance between the end of the snout and the fore limb nearly equals the distance between axilla and groin. Head twice and a half as long as broad; snout very long and pointed, much depressed. Lower eyelid with an undivided transparent disk; nostril pierced in the middle of the nasal; no supranasal; anterior loreal as deep as the nasal; frontonasal longer than broad, forming a broad straight suture with the rostral ; præfrontals forming a median suture; frontal small, acutely pointed behind, as long as the frontoparietals and interparietal together, in contact with the first and second supraoculars; four supraoculars, first large; seven supraciliaries; frontoparietals distinct, nearly as large as the interparietal, which is smaller than the frontal; parietals forming a suture behind the interparietal; three pairs of nuchals ; five upper labials anterior to the subocular. Ear-opening oval, smaller than the eye-opening, without lobules. 24 smooth scales round the middle of the body, dorsals largest, laterals smallest. Two enlarged præanals. The hind limb reaches the wrist of the adpressed fore limb. Digits depressed at the base, compressed at the end, third and fourth equal; subdigital lamellæ smooth, 19 under the fourth toe. Dark brown above, with three 
white, black-edged longitudinal streaks, the middle extending to the end of the snout, the outer to the eyes; tail golden; upper lip and lower parts white.

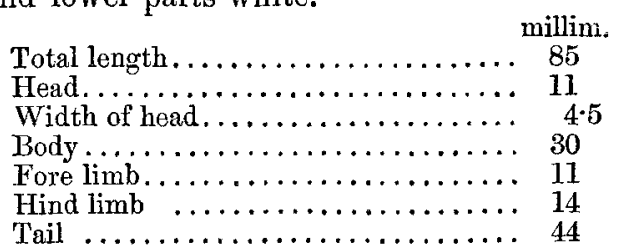

A single specimen.

Dendrelaphis papuensis.

Maxillary teeth 21 or 22. Eye as long as its distance from the nostril. Rostral broader than deep, visible from above; internasals as long as the præfrontals ; frontal once and a half to once and two thirds as long as broad, as long as its distance from the end of the snout, a little shorter than the parietals; loreal elongate; one præ- and two postoculars; temporals $2+2$; eight upper labials, fourth and fifth entering the eye ; five or six lower labials in contact with the anterior chinshields, which are shorter than the posterior. Scales in $\mathbf{1 3}$ rows. Ventrals 185-190; anal divided; subcaudals 119126. Olive-brown above, head and neck dark, blackish; a black streak on each side of the head and neck, passing through the eye; upper lip white; vertebral scales on anterior part of body lighter, edged with whitish in front; ventrals and subcaudals pale olive.

Total length 1050 millim.; tail 310.

Several specimens.

The same collection contains, among other more widely distributed reptiles, examples of Lepidodactylus pulcher, Blgr.; Lygosoma virens, Ptrs. (with 32 or 34 scales round the body); L. Mivarti, Blgr.; and Hyla infrafrenata, Gthr.

LIV.-Descriptions of new Genera of Zephroniidæ, with brief preliminary Diagnoses of some new Species. By R. I. Pocock.

Genus Spharotherium, Brandt.

Spharotherium, Brandt, Bull, Mosc. vi. p. 198, 1833 (=Oligaspis, Wood).

Resembling Zephronia in the structure of the vulva; the copulatory feet of the second pair in the male differing in being furnished with a strong stridulating-ridge. 